\title{
Correction to: Analysis of Promiscuous T cell Epitopes for Vaccine Development Against West Nile Virus Using Bioinformatics Approaches
}

\author{
Pawan Sharma $^{1,2} \cdot$ Priti Sharma $^{3} \cdot$ Sukrit Srivastav $^{2} \cdot$ Sanjay Mishra $^{1} \cdot$ Ajay Kumar $^{4}$
}

Published online: 27 October 2017

(c) Springer Science+Business Media, LLC 2017

\section{Correction to: Int J Pept Res Ther \\ DOI 10.1007/s10989-017-9624-2}

The original version of this article unfortunately contained an error. One of the author name Sukrit Srivastav and his affiliation details was inadvertently omitted from the author group. The author's name and affiliation are now included in this correction.

The online version of the original article can be found under doi:10.1007/s10989-017-9624-2.

Ajay Kumar ajaymtech@gmail.com

1 School of Biotechnology, IFTM University, Lodhipur Rajput, Delhi Road (NH-24), Moradabad 244001, India

2 Institute of Engineering and Technology, Mangalayatan University, Aligarh 202145, India

3 D. S. Degree College, Aligarh, Dr. B. R. Ambedkar University, Agra 282004, India

4 Department of Biotechnology, Rama University, Uttar Pradesh, Kanpur 209217, India 